Historic, Archive Document

Do not assume content reflects current scientific knowledge, policies, or practices. 

621173

The Logan Nurseries

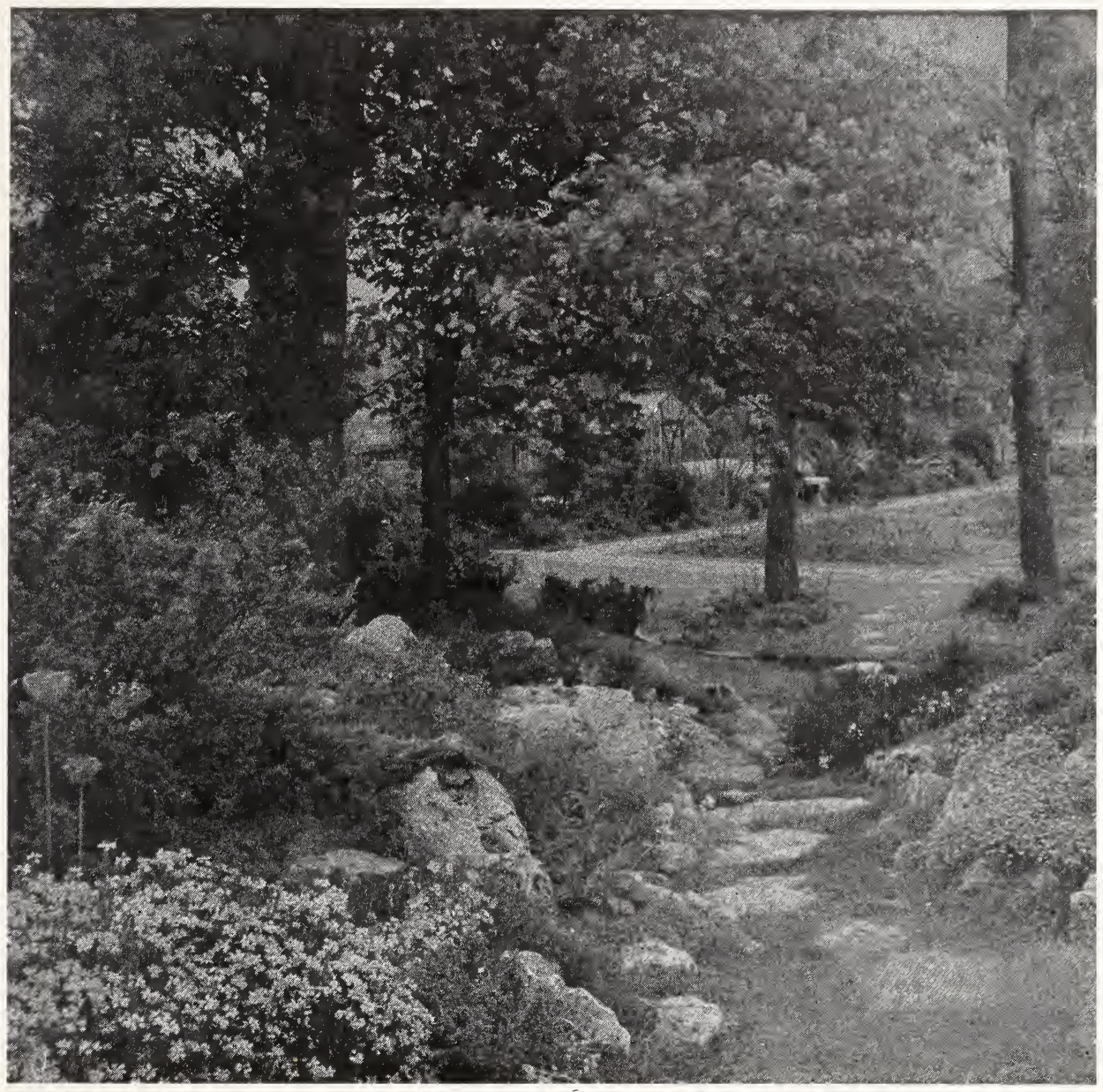

Rock Plants $\mathcal{E}$ Perennials

Bethlehem Pike

Bus Stop 33
MARY F. WRIGHT

AMBLER, PA.
Bell Phone,

Ambler 218 


\section{READ BEFORE O R D ER I N G}

SHIPPING-Give explicit directions as to address and mode of shipment. Orders without instructions will have our best judgment as to forwarding. Place your order early, as our stock of some varieties is limited.

STOCK-Periodically inspected by Federal and State Supervisors. A certificate of inspection accompanies each order.

PRICE-Extra sized or personally selected plants will be charged for at advanced prices to fit their value. Special price per 100 on many varieties; 30 sold at the 100 rate. Shipping orders for less than $\$ 5.00$ not solicited.

CLAIMS-All goods are shipped at purchaser's risk after they are delivered to the forwarding company. All other claims must be made to our office within three days of receipt of goods.

BULBS-Orders taken in Spring for Fall delivery. Dwarf varieties a specialty.

NOVELTIES-In addition to the plants listed in this catalogue, we have on hand limited quantities of other new and unusual rock plants. Send us your list of wants and we will quote prices.

Iris, Peonies, Roses and Evergreens not listed here can bc secured for our customers from the leading specialists.

VISITORS are welcome. Nursery open week days. Closed on Sunday except by appointment.

\section{THE GIFT SHOP}

Letitia E. Wright, Jr.

A cordial invitation is extended to all to visit the Gift Shop, where articles of interest for the garden as well as for the home may be seen.

Garden Accessories; Pottery; Vases; Honey in plain and fancy jars; distinctive and unusual Greeting Cards for all occasions; hand woven and hand embroidered Linens; Lamps and Rugs.

Articles suitable for Weddings, Bridge Prizes, Birthday and Christmas Gifts may be seen. 
I PRESENTING the following list of ROCK PLANTS and PERENNIALS, we do so in I full confidence that those listed will give the maximum of pleasure and enjoyment for the minimum of care and attention.

Our list is overflowing with Nature's choicest floral gems-tiny jewels-from distant Alpine heights, supplemented with little-known beauties of our own U. S. From the four corners of the globe we have received and marshalled in our nurseries a most bewildering array of these tiny floral beauties. From the very outposts of the civilized world, cohorts of these gorgeous little plants have been received and have been carefully acclimated in our nurseries and are now ready to brighten the precincts of your rock garden and borders.

Sturdy Lilliputians they are, full of vigor, carefully grown, and from their prodigal display with us, we know they will prove welcome additions to your more intimate gardens.

ACHILLEA tomentosa (Yarrow). A low growing sort with gray-green, ferny foliage and bright yellow flowers in July. 6 in. Ea. $30 \mathrm{c} ; 3$ for $75 \mathrm{c}$.

ACONITUM fisheri (Monkshood). Handsome spikes of lovely light blue flowers set off by very attractive foliage. Suitable for part shade. 3 to $4 \mathrm{ft}$. Sept. Ea. $50 \mathrm{c} ; 3$ for $\$ 1.30$.

ACTAEA alba (Baneberry). Attractive spike of white flowers, followed by clusters of white berries in June. Native. For shady places. $11 / 2 \mathrm{ft}$. Ea. $40 \mathrm{c} ; 3$ for $\$ 1.00$.

rubra. Showy spikes of white flowers followed by clusters of red berries in June. A native for shady spot. $1 \frac{1}{2} \mathrm{ft}$. Ea. $40 \mathrm{c} ; 3$ for $\$ 1.00$.

AETHIONEMA grandiflora (Persian Candytuft). Lovely gray-green foliage with terminal clusters of soft rosy pink flowers in May. Sunny spot, sandy soil. 10 in. Other varieties in limited quantity. Ea. 50c; 3 for $\$ 1.30$.

AJUGA alba (Bugle). A rapid creeper, forming a mat of thick green foliage with pretty white flowers in early summer. 8 in. Ea. 30 c; 3 for $75 c$.

reptans. Similar to the above, but with lovely bronze-green foliage and pretty blue flowers. 8 in. Ea. 30 c; 3 for 75 c.

ALYSSUM argenteum (Silver Alyssum). Small gray-green foliage with large flat corymbs of tiny yellow flowers in July. 15 in. Ea. $30 \mathrm{c} ; 3$ for $75 \mathrm{c}$.

saxatile compactum (Basket of Gold). Fine, rather large gray-green foliage with an abundance of bright yellow flowers in April. 12 in. Ea. 30 c; 3 for $75 c$.

citrinum. A very choice type with flowers of a delicate citron-yellow, enhanced by its gray-green foliage. April. 12 in. Ea. 40c; 3 for $\$ 1.00$.

serpyllifolium. Yellow flowers in June, compact hoary leaves. 4 in. Ea. 40c; 3 for $\$ 1.00$.

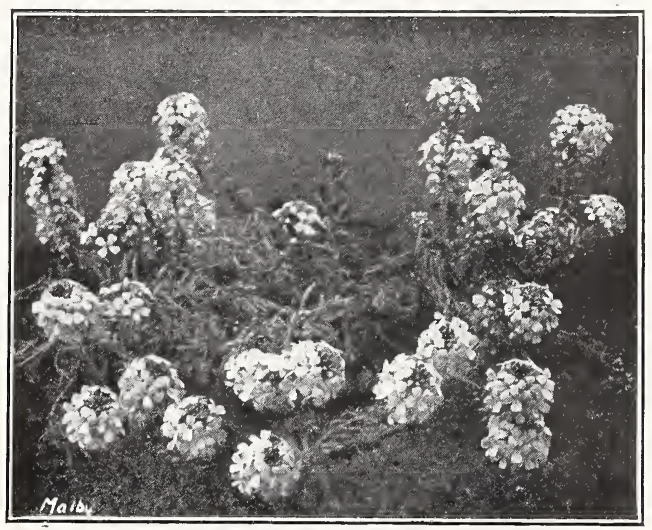

AETHIONEMA

ALCHIMILLA (Lady's Mantle). Robust grower, flowers small yellow in June. 12 in. Ea. 30 c; 3 for 75 c.

ANCHUSA myosotidiflora (Siberian Bugloss). Forget-me-not-like flowers of rich blue on wiry 12-in. stems. Leaves large. May. Ea. 40 c; 3 for $\$ 1.00$.

ANDROSACE lanuginosa. Flowers pale pink, silvery foliage; trailing. Summer blooming. 3 in. Ea. $75 \mathrm{c} ; 3$ for $\$ 2.00$.

primuloides (Rock Jasmine). A high Alpine from the Himalayas, forming compact rosettes of gray-green foliage and in April sending up on wiry stems umbels of very dainty pink flowers. As rare as it is beautiful. 3 in. Ea. $50 \mathrm{c} ; 3$ for $\$ 1.30$.

*Sold out for Spring delivery, will be ready by Fall, 


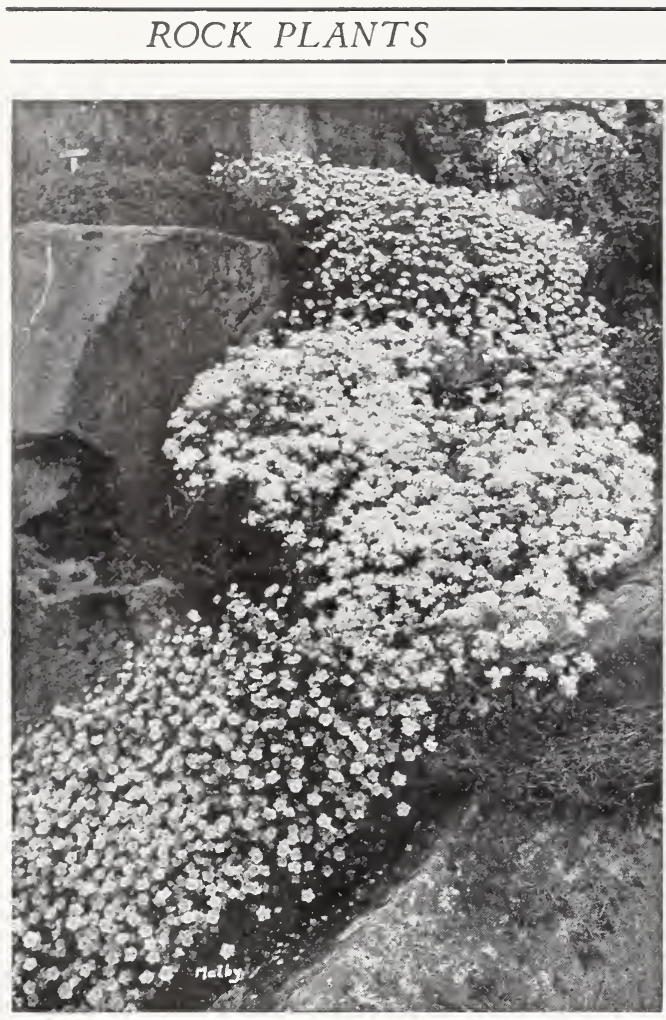

A CASCADE OF AUBRIETIA, ALYSSUM AND MOSSY SAXIFRAGES

ANEMONE hupehensis. Flowers mauve-pink, early fall. About 20 in. tall. Dainty and attractive. Ea. $30 \mathrm{c} ; 3$ for $75 \mathrm{c}$.

pulsatilla (Pasque flower). Ferny, silky, gray-green foliage, from which, in early April, spring goblet-shaped flowers of delicate lavender. Handsome seed pods decorate this plant for a month after bloom is over. 10 in. Ea. 40c; 3 for $\$ 1.00$.

ANTHEMIS aizoon (syn. Achillea Ageratifolia). Tufts of narrow silvery green foliage with small white, double daisy-like flowers in May. 8 in. Very choice. Ea. 50c; 3 for $\$ 1.30$.

AQUILEGIA caerulea (Rocky Mountain Columbine). Exquisite long-spurred flowers of delicate blue and white, with maiden-hair fern-like foliage. May. 18 in. Ea. 30c; 3 for $75 \mathrm{c}$.

canadensis. A native columbine with attractive foliage and an abundance of red and yellow flowers in May. 10 in. Ea. 30c; 3 for $75 \mathrm{c}$.

\section{AQUILEGIA -Cont'd}

oxypetala. Blue and white flowers, early and dwarf. 10 in. Ea. 40c; 3 for $\$ 1.00$.

chrysantha. Another long-spurred beauty with soft yellow flowers in June. A very fine plant. 24 in. June. Ea. 30c; 3 for 75c.

"pink hybrids." These are long-spurred hybrids coming in a bewildering variety of soft pastel pink shades. These are very choice. 20 in. Nay-June. Ea. 40c; 3 for $\$ 1.00$.

"hybrids." An assortment of superlative longspurred flowers in a host of glorious shades. May. Ea. 30c; 3 for 75 c.

ARABIS alpina (Rock cress). Formus cascades of gray foliage with an abundance of pure white flowers in very early spring. Charming with blue buibs of Chionodoxa or Scilla. 8 in. Ea. $30 \mathrm{c} ; 3$ for $75 \mathrm{c}$.

-fl. pl. A double flowered form of the above which is choicer and rarer than the type. Aprit. 8 in. Ea. $40 \mathrm{c} ; 3$ for $\$ 1.00$.

mollis. Deep green mats of foliage with dainty white flowers which appear in April. 8 in. Ea. $30 \mathrm{c} ; 3$ for $75 \mathrm{c}$

ARCTOSTAPHYLOS uva-ursi (Bearberry). A prostrate evergreen ground cover with rich dark green foliage; white flowers, red berries. Requires acid soil. 5 in. Ea. $75 \mathrm{c}$; 3 for $\$ 2.00$

ARENARIA montana (Sandwort). A very pretty low growing creeper with a galaxy of white flowers in June. 6 in. Ea. 30c; 3 for $75 \mathrm{c}$.

ARISAEMA triphyllum (Jack-in-the-pulpit). A native for planting in shade in the rock or wild garden. Greenish-white flowers, followed by red berries. 15 in. Ea. 25c; 3 for $60 \mathrm{c}$.

ARMERIA maritima (Sea Pink or Thrift). Tufts of grass-like foliage with pink pomponns of tiny flowers. 6 in. Ea. 30c; 3 for $75 c$.

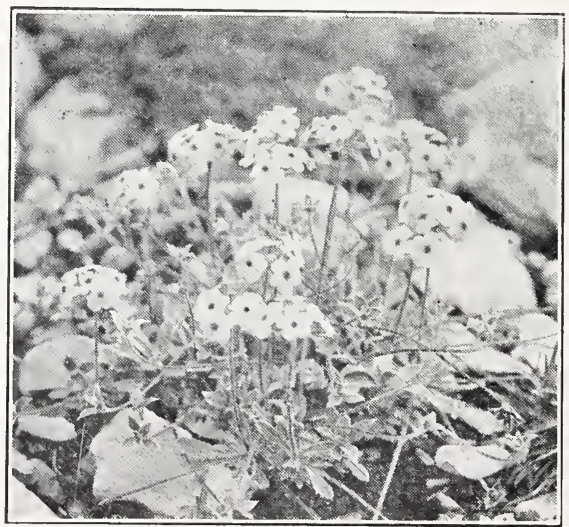

ANDROSACE

*Sold out for Spring delivery, will be ready by Fall. 


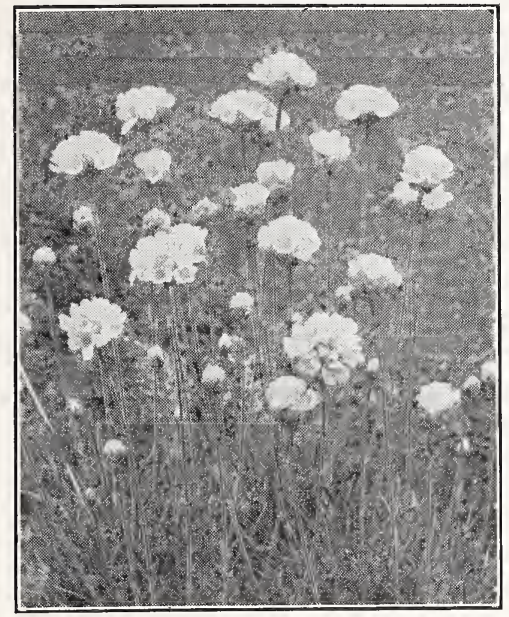

ARMERIA

\section{ARMERIA-Cont'd}

- alba. The white counterpart of the above. May. 6 in. Ea. 30c; 3 for $75 c$.

laucheana. A very choice type with rich carmine colored flowers. Blooms in May and again in early Fall. 6 in. Ea. 30c; 3 for $75 \mathrm{c}$.

ARTEMISIA frigida (Fringed Wormwood). Soft, silvery gray, glossy, finely cut foliage. Flowers insignificant. Sunny situation. 6 to 10 in. Ea. $50 \mathrm{c} ; 3$ for $\$ 1.30$.

ASCLEPIA tuberosa (Butterflyweed). Flowers brilliant orange-scarlet in July and August. A showy native plant. 24 in. high. Good for cutting. Ea. 30c; 3 for $75 c$.

ASPERULA odorata (Sweet Woodruff). Snowy white flowers in May. Fragrant green foliage. Ground cover. Does better in shade than in sun. 8 in. Ea. 30c; 3 for $75 c$

ASTER alpinus (Rock Aster). Pretty soft lavender flowers with yellow centers. Most effective in groups. May. 6 in. Ea. 30c; 3 for $75 \mathrm{c}$.

"Mauve Cushion." Forms cushion-like mounds which in the late Fall are covered with small mauve daisies. 10 in. Ea. 30c; 3 for $75 c$

"Queen Mary." Large lavender flowers. October. $2 \mathrm{I} / 2 \mathrm{ft}$. New. Ea. $50 \mathrm{c} ; 3$ for $\$ 1.30$.

AUBRIETIA hybrida (False Rockcress). Lovely hybrids in various shades of lavender. Gray foliage. Prostrate creeper. April. 6 in. Ea. $40 \mathrm{c} ; 3$ for $\$ 1.00$.
CAMASSIA leichtlini (Indian Quamash). A native bulbous plant with long spikes of pretty lavender flowers. Shady spot suits this plant. June. $2 \frac{1}{2}-3$ ft. 3 bulbs for $45 \mathrm{c}$; per $10, \$ 1.00$.

- alba. A counterpart to the above with white flowers. June. $2 \mathrm{I} / 2-3 \mathrm{ft}$. 3 bulbs for $45 \mathrm{c}$; per $10, \$ 1.00$.

CAMPANULA carpatica (Carpathian bellflower). A charming plant with soft blue flowers held well above the dark green foliage. June. 10 in. Ea. 30c; 3 for 75 c.

- "Riverslea." Flowers large, flatish clear blue, a handsome form. July and August. 10 in. Ea. 35 c; 3 for 90 c.

garganica (Gargano Harebell). Delightful pale blue, starfish flowers on close tufts of pointed heart-shaped leaves. A choice variety. 4 in. Ea. 50 c; 3 for $\$ 1.30$.

glomerata acaulis (Low Cluster Bellflower). Large clusters of rich violet flowers, very dwarf. Ea. 35c; 3 for 90c.

lactiflora (Milky Bellflower). Pale Blue flowers during July and August. 24 in. Ea. $30 \mathrm{c}$; 3 for $75 \mathrm{c}$.

portenschlagiana (Dalmatian Bellflower). A tufty little gem with green foliage, which in June is hidden by myriads of little deepblue bells. Should be in every rock garden. 4 in. Ea. 50c; 3 for $\$ 1.30$.

rotundifolia (Harebell). Dainty spikes of deep blue flowers, rather pendent in habit. Ea. $30 \mathrm{c}$; 3 for $75 \mathrm{c}$.

CERASTIUM tomentosum (Snow in Summer). A rapid growing creeper with gray foliage and covered with little white flowers in May. 8 in. Ea. 30c; 3 for 75 c.

CERATOSTIGMA plumbaginoides (Leadwort). A splendid plant with bronzy green foliage and clusters of gentian blue flowers from early Fall till frost. 10 in. Ea. 30c; 3 for $75 c$

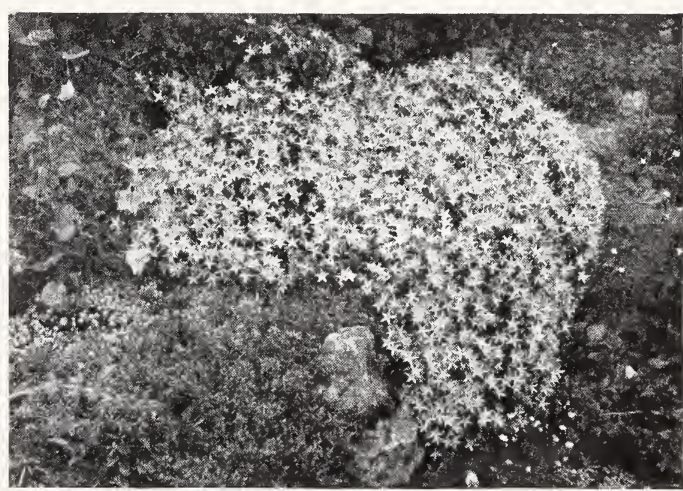

CAMPANULA GARGANICA

*Sold out for Spring delivery, will be ready by Fall. 
*CHEIRANTHUS allioni. Vivid orange flowers in profusion. Treat as a biennial. May. 12 in. Ea. 30c; 3 for 75 c.

linifolius. A dainty mauve cushion, very free flowering. Ea. 40c; 3 for $\$ 1.00$.

CHRYSANTHEMUM. We have a fine assortment of hardy large-flowered and pompom types, early and mid-season, in various shades of pink, white, bronze and yellow. Ea. $30 \mathrm{c} ; 3$ for $75 \mathrm{c}$.

coccineum (Pyrethrum). Daisy-like flowers in various shades of red, through pink to white. Good for cutting. 20 in. June. Ea. $30 \mathrm{c} ; 3$ for $75 \mathrm{c}$.

DELPHINIUM "Belladonna" (Larkspur). Soft sky-blue flowers loosely arranged along strong spikes. A beautiful sort. June and Sept. 2-3 ft. Ea. 30c; 3 for $75 \mathrm{c}$.

chinensis. Lovely porcelain blue flowers in great profusion. Fine for massing in borders or corners of rock garden. 18 in. Ea. $30 \mathrm{c}$; 3 for $75 \mathrm{c}$.

"English hybrids." A very fine assortment from the choicest seeds. Various shades of blue. Exquisite subjects for beds or borders. 3-5 ft. June and Sept. Ea. 75c; 3 for $\$ 2.00$.

DIANTHUS arenarius (Sand Pinks). A profusion of white flowers with fringed petals. Fragrant. June. 8 in. Ea. 40 c; 3 for $\$ 1.00$.

barbatus (Sweet William) "Newport Pink." A very charming shade of watermelon pink. June. 18 in. Ea. 30c; 3 for 75 c.

— "Fairy." Delightful pale pink flowers in clusters. June. 18 in. Ea. 30c; 3 for 75 c.

brevicaulis. A little atom with cushions of soft gray-green foliage, which in June is starred with soft pink blossoms. A little gem. 3 in. Ea. 50c; 3 for $\$ 1.30$.

deltoides (Maiden pink). A rapid creeper, forming a cataract of bright pink blossoms in June. 6 in. Ea. $30 \mathrm{c} ; 3$ for $75 \mathrm{c}$.

- albus. Same as above with white flowers. Ea. 30c; 3 for 75 c.

integer. A pygmy sort forming a close mat of deep green foliage with white or pale pink flowers. Dainty and rare. Ea. 30c; 3 for $75 \mathrm{c}$.

neglectus, "The Glacier Pink." Regarded by experts as the very choicest of the race. Petals are carmine pink with buff reverse. Tufty grass-like foliage. A real treasure. 4 in. Ea. 50 c; 3 for $\$ 1.30$.

plumarius. Flowers fragrant in shades of pink; good for cutting, glaucous foliage. Ea. $30 \mathrm{c} ; 3$ for $75 \mathrm{c}$.

pritchardi. A Lilliputian with minute foliage and bright pink flowers. A fine creeper. 3 in. May. Ea. $75 \mathrm{c} ; 3$ for $\$ 2.00$.

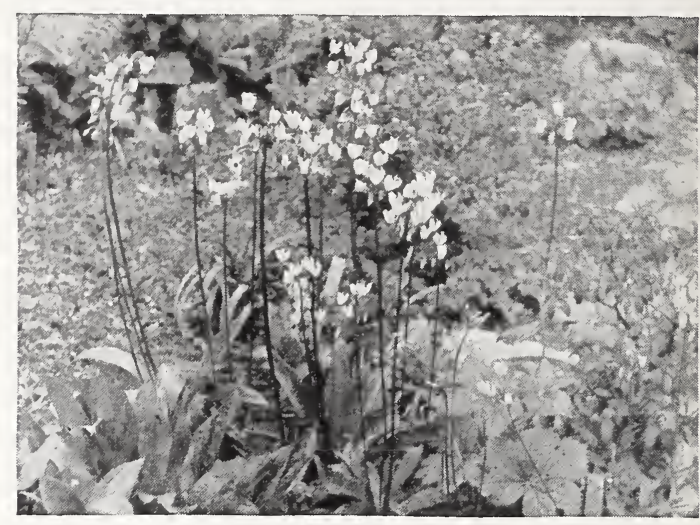

DODECATHEON MEDIA

DICENTRA eximia (Fringed Bleeding Heart). Plumy, lace-like foliage crowned with racemes of pink flowers all summer long. A choice plant. 15 in. Ea. $30 \mathrm{c} ; 3$ for $75 \mathrm{c}$.

spectabilis. Old-fashioned favorite, graceful sprays of pink heart-shaped flowers. $20 \mathrm{in.}$ Ea. 60c; 3 for $\$ 1.50$.

DIGITALIS (Foxglove). A biennial. White or various shades of pink on a 30 -in. spike. June. Ea. 30c; 3 for $75 c$.

DODECATHEON meadia (Shooting Star). From a basal tuft of foliage the lovely white or pink flowers appear in early sum. mer. 12 in. Ea. 35c; 3 for 90 c.

DORONICUM (Leopardbane). A very charming plant with numerous large, daisy-like flowers in soft yellow shades. Fine for cutting. Blooms in April. 18 in. Ea. 50c; 3 for $\$ 1.30$.

DRABA repens. It forms a charming dwarf carpet and produces yellow flowers early in April. 3 in. Ea. $50 \mathrm{c} ; 3$ for $\$ 1.30$.

EPIMEDIUM alpinum. Flowers red and yellow in April. Foliage interesting. Excellent for the shade. 8 in. Ea. 50c; 3 for $\$ 1.30$.

ERINUS alpinus albus. White flowers; only 4 in. high. Rosettes of dainty foliage. May, June. Ea. $40 \mathrm{c} ; 3$ for $\$ 1.00$.

ERODIUM (Heronsbill). Several varieties in limited quantity. Ea. 40c.

ERYTHRONIUM (Dog-tooth violet). A native bulb; good for semi-shade. Other varieties if requested.

grandiflorum robustum. Flowers brightest buttercup yellow. Leaves have no mottling. 3 for $50 \mathrm{c} ; 100$ for $\$ 6.00$.

revoltum johnsonii. Rose-pink flowers, perhaps the most lovely of all. 3 for $80 \mathrm{c}$; 100 for $\$ 10.00$.

*Sold out for Spring delivery, will be ready by Fall. 


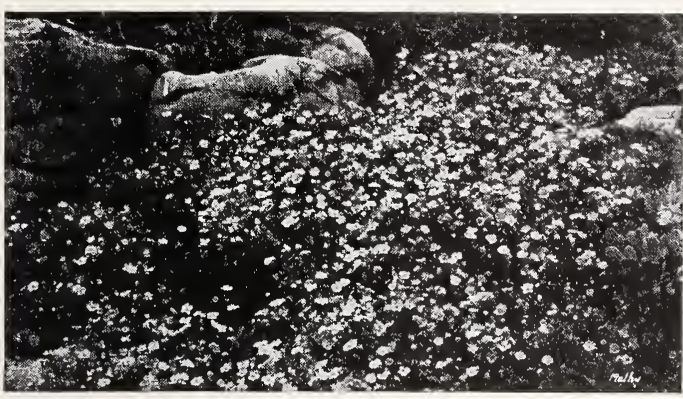

HELIANTHEMUM (Sunrose)

EUONYMOUS kewensis (Wintercreeper). A delightful little evergreen creeper forming prostrate mats of fine dark green foliage. Ea. 30c; 3 for $75 c$.

EUPATORIUM coelestinum (Mistflower). A fine border plant with clusters of lavender blue flowers in September when flowers are scarce. Fine for cutting. $2 \mathrm{ft}$. Ea. 30c; 3 for $75 \mathrm{c}$.

EUPHORBIA myrsinties (Spurge). A prostrate plant with masses of soft gray-green foliage and yellow flowers in March. 8 in. Ea. $50 \mathrm{c} ; 3$ for $\$ 1.25$.

FERNS. We offer a very fine and choice assortment of the better kinds for use in the rock or wild garden. Ea. 30c; 3 for $75 c$.

FILIPENDULA hexapetala fl. pl. (syn. Spiraea filipendula). A handsome plant with delicate fern-like foliage and clusters of double white flowers. 18 in. Ea. 40c; 3 for $\$ 1.00$.

FESTUCA glauca (Blue Festuca). Dwarf grass with tufted blue-green foliage. $12 \mathrm{in.} \mathrm{Ea.}$ $30 \mathrm{c}$; 3 for $75 \mathrm{c}$.

GALAX aphylla (Wand flower). A pretty native plant, for shady places, with evergreen bronzy leaves and scapes of white flowers. 18 in. Ea. 40c; 3 for $\$ 1.00$.

GENISTA sagittalis (Arrow Broom). Stems prostrate, winged like an arrow, suggestive of a cactus; flowers yellow. May. 6 in. Ea. $50 \mathrm{c} ; 3$ for $\$ 1.30$.

GENTIANA andrewsii (Gentian). The native "closed or bottle gentian." Blue-bird blue flowers in terminal clusters. Sept. 20 in. Ea. $30 \mathrm{c} ; 3$ for $75 \mathrm{c}$.

porphyrio (Pine-barren Gentian). Beautiful blue flowers in autumn. $18 \mathrm{in.} \mathrm{high.} \mathrm{Needs}$ an acid soil. Ea. 75c.

*lagodechiana. An exquisite prostrate gem with deep sapphire-blue trumpets in September. Rare and choice. 6 in. Ea. $\$ 1.00$.

*farreri. Drooping shoots, narrow foliage, pale blue trumpet flower. For a very choice spot, only a few. 4 in. Ea. $\$ 2.00$.
GERANIUM argenteum (Silver Cranesbill). Foliage like shimmering hoar-frost or glistening silver. The pale pink flowers suggest single roses. 6 in. Ea. 50c; 3 for $\$ 1.30$. sanguineum alba. Large, rampant shrubby grower, white flowers in June. 18 in. Ea. $35 \mathrm{c} ; 3$ for $90 \mathrm{c}$.

- lancastriense. Dwarf and compact form, with pink flowers. Ea. 75c.

GEUM (Avens) "Lady Stratheden." Flowers double, rich golden yellow. Summer blooming. 18 in. Ea. $30 \mathrm{c} ; 3$ for $75 \mathrm{c}$.

"Mrs. Bradshaw." Double flowers of fiery red. Summer blooming. 18 in. Ea. 30c; 3 for $75 c$.

GLOBULARIA Nana. Tiny leaves, close growing ground cover. Flower-heads like blue balls in June. Ea. 50c; 3 for $\$ 1.30$.

GYPSOPHILA cerastoides (Mouse-eared Chalkplant). A dainty little plant with white, red-veined flowers. Low growing and choice. June. 8 in. Ea. $40 \mathrm{c} ; 3$ for $\$ 1.00$.

repens. Fine trailing gray-green foliage studded with a cloud of little white flowers in June. 8 in. Ea. 30 c; 3 for $75 c$.

HEDERA helix (Ivy). Climbing evergreen vine. Young plants, 3 in. pot. Ea. 25c; 3 for $75 \mathrm{c}$. Larger plants $50 \mathrm{c}$ each and upward.

HELENIUM “Riverton Gem." Flowers yellow, changing to wallflower red. A good cut flower. September. $5 \mathrm{ft}$. Ea. 30c; 3 for $75 \mathrm{c}$.

HELIANTHEMUM (Sun Rose). Excellent plants for the full sun in poor soil, foliage semi-evergreen. We can supply the following separate colors: Clear yellow, orange, and a beautiful shrimp pink. Ea. 35c; 3 for $85 \mathrm{c}$.

HERNIARIA glabra. Dwarf ground cover, excellent between stepping stones. $I / 2$ in. Ea. 35c; 3 for 90c.

HEUCHERA (Coral Bells). Neat, compact semi-evergreen foliage from which in June issue spikes of pretty bells. Fine for cuting.

pale pink. 24 in. Ea. 35 c; 3 for 85 c.

glowing red. 15 in. Ea. $50 \mathrm{c} ; 3$ for $\$ 1.25$.

HOSTA undulata variegata (Plaintain Lily) (syn. Funkia). Pale lavender flowers in August. The foliage is very handsomely variegated green and white. 12 in. Ea. 30c; 3 for $75 \mathrm{c}$.

HÝPERICUM buckleyi (St. John's Wort). A native plant of fine habits with pretty yellow flowers over a long period in summer. 8 in. Ea. $75 \mathrm{c} ; 3$ for $\$ 2.00$.

*coris. The gem of this race with tiny green, heather-like foliage and soft yellow flowers. The flowers contrast prettily against the blue-green foliage. A real gem. July. 6 in. Ea. 75c.

repens. Bright yellow flowers, a choice dwarf carpeter. 4 in. Ea. 60 c; 3 for $\$ 1.60$. 


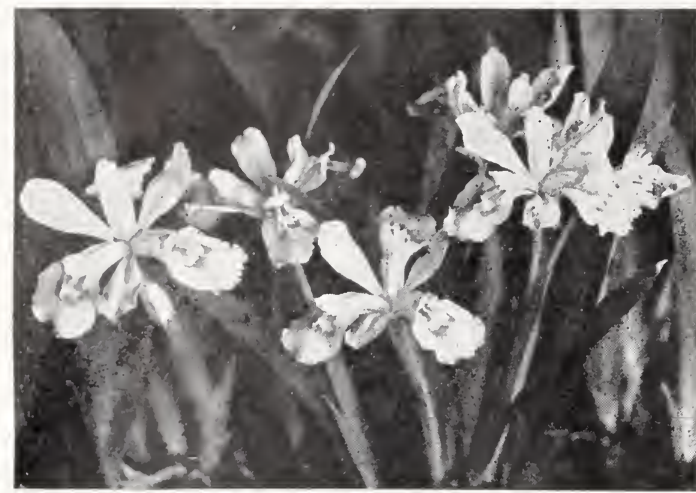

IRIS CRISTATA

IBERIS sempervirens "Snow Flake" (Perennial Candytuft). Dark evergreen foliage, which sets off the brilliant snow-white flowers. May. 10 in. Ea. 30c; 3 for 75 c.

— "Little Gem." Aptly named, as it is a little beauty of very compact growth. Evergreen foliage and white flowers. 6 in. Ea. 30c; 3 for $75 \mathrm{c}$.

IRIS arenaria. Keen rock gardeners will certainly want this rare little gem. Only 4 inches high, it offers us the most delightful flowers of soft Nankeen yellow with brown beard. In addition to this, it is delightfully fragrant. Very rare and our stock is linited. May. Ea. $\$ 2.00 ; 3$ for $\$ 5.00$.

cristata. The native crested iris. Lavender blosoms with yellow crest. Charming and dainty. 4 in. May. Ea. 30c; 3 for 75c.

dichotoma. "The Vesper Iris" of Japan. Small lavender flowers on branching stems. The flowers open in the afternoon. August. $3 \mathrm{ft}$. Ea. $75 \mathrm{c} ; 3$ for $\$ 2.00$.

gracilipes (Slender Iris). Flowers like pale blue, wide-winged butterflies of sheerest, crumpled silk. Requires part shade, with no lime. 12 in. Ea. \$1.00. July delivery only. pumila hybrida. A lovely little iris with deep purple flowers that appear in May. 10 in. Ea. 30c; 3 for $75 c$.

- azurea (syn. coerulea). Dwarfer than the above-6 in.- but with lovely sky-blue flowers in May. A fine variety. Ea. 50c; 3 for $\$ 1.30$.

setosa canadensis (Arctic Iris). Native of northern sandy beaches, blue flowers. May. 10 in. Ea. $\$ 1.00$.

verna. A native evergreen species requiring acid soil, with lavender flowers which appear in May. 4 in. Ea. 30c; 3 for $75 c$.

In addition to the above we can supply other varieties from the leading specialists.

LAMIUM maculatum (Spotted Deadnettle). Rapid grower, variegated leaves, flowers pink. May. 12 in. Ea. 30c; 3 for $75 c$.
LEONTOPODIUM alpinum (The Alpine Edelweiss). Flannel-like white flowerheads, gray foliage. Ea. 50c; 3 for $\$ 1.30$.

LEWISIA rediviva. Pink flowers, narrow leathery leaves in a rosette. 4 in. Ea. 50c; 3 for $\$ 1.30$

Other varieties in limited quantities.

LINARIA aequitriloba. Pretty lavender flowers in profusion. A flat ground cover of dainty foliage. Part shade. Walls or paths. $1 / 2$ in. Ea. $50 \mathrm{c} ; 3$ for $\$ 1.30$.

LINUM flavum (Flax). Delightful green foliage with striking clear yellow blooms in June and July. Splendid plant. 20 in. Ea. $30 \mathrm{c} ; 3$ for $75 \mathrm{c}$.

perenne. Another pretty kind with feathery blue-green foliage and sapphire-blue flowers which appear in June. 20 in. Ea. 30c; 3 for $75 \mathrm{c}$

LOBELIA cardinalis (Cardinal flower). Beautiful spike of red flowers, native along streams; does well in garden. July. 24 in. Ea. 30c; 3 for $75 c$.

MAZUS pumilio. One of the neatest and most rapid creepers, with tiny snapdragon-like flowers of mauve with yellow lip. Excellent for part shade. June. 1 in. Ea. 30c; 3 for $75 \mathrm{c}$.

MENTHA requieni (Requien Mint). Delightful low creeper, very fragrant, minute flowers. 2 in. Ea. 50c; 3 for $\$ 1.30$.

MERTENSIA Virginica (Bluebells). A native, with blue-green foliage and blue flowers with pink buds in April. Foliage disappears in June, reappearing early the following Spring. 18 in. Ea. 30c; 3 for $75 \mathrm{c}$.

MITCHELLA repens (Partridgeberry). A native of our woodlands, with deep evergreen foliage. Acid soil. 'The flowers are white and are succeeded by bright red berries. 2 in. Ea. 30c; 3 for $75 c$.

MUEHLENBECKIA nana (Wire Bush). A shrub-like creeper with minute leaves of a deep bronzy-green. A fine ground cover for rock garden bulbs. 4 in. Ea. 40c; 3 for $\$ 1.00$.

MYOSOTIS scorpioides (True Forget-me-not). Lovely light blue flowers, yellow centers. Best in a moist position. Ea. 30c; 3 for $75 \mathrm{c}$.

NEPETA mussini (Catmint). Hoary gray foliage, against which the soft lavender flowers look very effective. May. 18 in. Ea. 30c; 3 for $75 \mathrm{c}$.

OENOTHERA caespitosa (Evening Primrose). White flowers fading to pink as they age. Low basal tuft of leaves. Summer. 6 in. Ea. $50 \mathrm{c} ; 3$ for $\$ 1.30$.

fruticosa youngi. Bright yellow flowers in summer. 18 in. Ea. 30c; 3 for $75 \mathrm{c}$.

missouriensis. Large yellow flowers which appear in July and August. Fine for wall or border planting. 8 in. Ea. $30 c ; 3$ for 75 . 
PACHYSANDRA terminalis ( $\mathrm{J}$ a p a n e s e Spurge). A most useful evergreen ground cover for planting under trees where little else will grow. 8 in. Ea. 30c; 3 for $75 \mathrm{c}$.

PAEONIA (Peony). Hardy, long-lived oldfashioned plant. Showy, large flowers. Pink, wihte or red.

New Named Herbaceous Varieties. (Prices on request.)

P. offinalis rubra fl. pl. Early old-fashioned double red. Ea. $\$ 1.00$.

"Single Japanese Tree Peonies" from a noted grower. Pink, white or red by color. Price $\$ 5.00 \mathrm{up}$-according to size, shape and number of the same variety available.

PAPAVER nudicaule (Iceland Poppy). Cupshaped flowers, white, yellow or orangescarlet. 12 in. Ea. 30c; 3 for $75 c$.

PENTSTEMON coeruleus. A delightful plant with soft blue flowers in May. 12 in. Ea. $35 c$; 3 for 90 c.

PHLOX amoena. A native phlox with rich deep green leaves and brilliant pink flowers in early May. 6 in. Ea. 30c; 3 for 75 c.

bifida. Pale violet, deeply cleft flowers, native west of the Allegheny Mountains. Rare in cultivation. Ea. 50c; 3 for $\$ 1.30$.

divaricata, var. "Laphamii." A native of our woodlands. Evergreen leaves and periwinkle blue flowers in May. Fragrant and desirable. 10 in. Ea. 40c; 3 for $\$ 1.00$.

ovata. Deep pink flowers. 15 in. Ea. 30c; 3 for $75 c$.

suffruticosa "Miss Lingard." White with faint lavender eye. Fragrant, blooming in June. $2 \mathrm{ft}$. Ea. 30c; 3 for $75 \mathrm{c}$.

subulata. Indispensable evergreen creepers, with moss-like foliage, hidden by flowers during blooming season.

- alba. White flowers in profusion. May. 4 in. Ea. 30c; 3 for $75 \mathrm{c}$.

- "Apple Blossom." Beautiful pale pink flowers. New. May. Ea. 50c; 3 for $\$ 1.30$.

- “G. F. Wilson." Fine lavender flowers. Most desirable. May. 6 in. Ea. 30c; 3 for $75 \mathrm{c}$

- rosea. The popular "Mountain Pink" or "Moss Pink." A profusion of bright pink flowers in early spring. 5 in. Ea. 30c; 3 for $75 \mathrm{c}$.

- "Vivid." The brightest, purest pink of the subulata. Brilliant flowers hide the tufty moss-like foliage. Very dwarf. 3 in. Ea. $35 \mathrm{c} ; 3$ for $90 \mathrm{c}$.

PINKS. See Dianthus on page ?.

PLUMBAGO. See Ceratostigma plumbaginoides on page?.

POLEMONIUM repens (Jacob's Ladder). A lovely plant with lacy foliage and bright light blue flowers in early May. Succeeds best in part shade. 10 in. Ea. 30c; 3 for $75 \mathrm{c}$.
POTENTILLA tonguei. Flowers deep yellow, red center, of trailing habit. Rare. Ea. 60c. tridentata (Wineleaf Cinquefoil). White strawberry-like blossoms; foliage deep glossy green, which turns scarlet in the Fall. Requires an acid soil. 8 in. Ea. 40c; 3 for $\$ 1.00$.

verna nana. Here we offer the gem of the race. The plant forms close mat of pretty foliage, above which appear the brilliant yellow flowers in April. Rare and beautiful. 3 in. Ea. 50c; 3 for $\$ 1.30$.

PRIMULA denticulata. Large globular heads in various shades of lilac. Enjoys a cool or moist situation. Ea. $40 \mathrm{c} ; 3$ for $\$ 1.00$.

polyantha. Various colors; a good English strain. Ea. 30c; 3 for $75 c$.

PRUNELLA grandiflora rubra (Selfheal). Rapid grower, thick mat; suitable for less choice situations. Pink. July. 8 in. Ea. $30 \mathrm{c} ; 3$ for $75 \mathrm{c}$

PULMONARIA azurea (Lungwort). Gentian blue flowers, large dark green hairy leaves. April. 8 in. Ea. 50c; 3 for $\$ 1.30$.

saccharata. Pretty foliage with white motlings. Flowers pink to blue. A charming plant. 12 in. Ea. 50 c; 3 for $\$ 1.30$.

PYRETHRUM. See Chrysanthemum.

PYXIDANTHERA barbulata (Pyxie Moss). Moss-like in growth. $1 / 2$ in. high. Covered with small pinkish-white flowers in earliest spring. Very acid soil required. Ea. 75c.

SANTOLINA cham. incana (Lavender cotton). Inconspicuous yellow flowers, but a foliage plant of first grade. Gray-green aromatic foliage. 15 in. Ea. $30 \mathrm{c}$; 3 for $75 \mathrm{c}$.

SAPONARIA ocymoides splendens (Rock Soapwort). A trailing plant with dark green foliage and clustered pink flowers in May. 6 in. Ea. 30c; 3 for 75 c.

SAXIFRAGA macnabiana (Rockfoil). Graygreen rosettes outlined with silvery encrustations. White flowers, speckled red in panicles in May. 10 in. Ea. 50c; 3 for $\$ 1.30$.

muscoides. A tufty little mossy-leaved plant with a profusion of white flowers in May. A dainty gem. 6 in. Ea. $50 \mathrm{c} ; 3$ for $\$ 1.30$.

megasea. Large leathery, dark green leaves with a spike of soft pink blooms in very early Spring. 10 in. Ea. 40c; 3 for $\$ 1.00$.

SEDUM acre (Stonecrop). Low growing mats of mossy foliage with a multitude of little yellow star-shaped flowers in May. Easy to grow. 3 in. Ea. $30 \mathrm{c} ; 3$ for $75 \mathrm{c}$.

album. A rapid grower, forming mats of succulent dark green foliage with white flowers in June. 5 in. Ea. 30c; 3 for 75 c.

dasyphyllum. A gem with little silvery gray beac-like leaves and pink flowers. Choice. 3 in. Ea. 50c; 3 for $\$ 1.30$. 


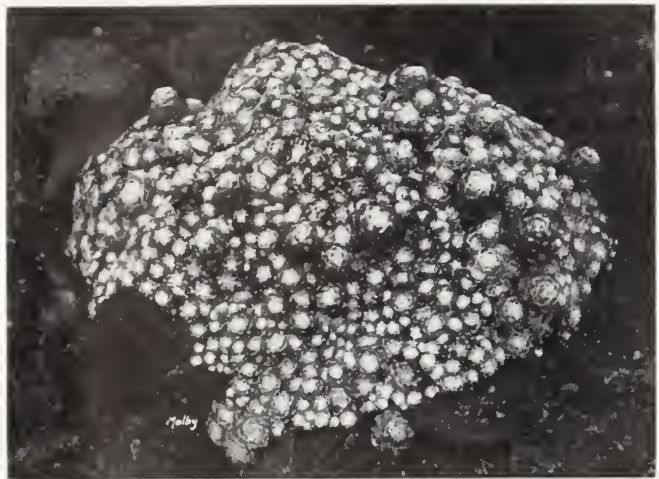

SEMPERVIVUM

\section{SEDUM-Cont'd}

ewersi. Blue-gray foliage and deep pink flowers. 10 in. July. Ea. 30c; 3 for $75 \mathrm{c}$.

kamtschaticum. Leaves dark green with orange-yeliow flowers in July. 8 in. Ea. $30 \mathrm{c} ; 3$ for $75 \mathrm{c}$.

lydium. Another very good kind with bright green foliage, which turns red in Winter. Makes a close mat. White flowers. $3 \mathrm{in}$. Ea. $30 \mathrm{c} ; 3$ for $75 \mathrm{c}$.

- glaucum. Foliage glaucus-green, choice. Ea. $30 c ; 3$ for $75 c$.

nevii. Rare native, close rosettes of gray foliage and white flowers. May. 5 in. Ea. $50 \mathrm{c} ; 3$ for $\$ 1.30$.

pulchellum. Leaves like small fir trees, pink flowers grouped like a starfish. May. 6 in. Ea. 40 c; 3 for $\$ 1.00$.

reflexum. Grayish-green foliage that looks like a club moss. Yellow flowers in July. Rapid grower. 6 in. Ea. 30c; 3 for $75 c$.

rupestris minor. A very attractive kind with blue-green foliage, which assumes reddish tints in the Fall. Yellow flowers in July. 8 in. Ea. 30c; 3 for 75 c.

sarmentosa. Low growing rapid creeper with yellow flowers in late Summer. Fine for covering waste spots. 4 in. Ea. $30 \mathrm{c} ; 3$ for $75 \mathrm{c}$.

sexangulare. Flowers yellow; a mat of dark green foliage. 4 to 6 in. Ea. $30 \mathrm{c} ; 3$ for $75 \mathrm{c}$.

sieboldi. Considered by many as the finest sedum in cultivation. A very pretty plant with round glaucous foliage with reddish margin. Its flowers, which appear in Sept., are deep pink. 6 in. Ea. 40 c; 3 for $\$ 1.00$.

spectabile. A tall growing kind with showy pink flowers in Sept. The foliage is graygreen and most attractive at all seasons. 12 in. Ea. 30c; 3 for 75 c.

\section{SEDUM-Cont'd}

spurium. A rapid creeper, the leaves of which turn red in Winter. Pink blossoms in late Summer. 6 in. Ea. 30c; 3 for 75 c.

ternatum. A native shade-loving sedum with fleshy leaves and white flowers which appear in May. Attractive and desirable. 3 in. Ea. 30c; 3 for $75 c$

SEMPERVIUM. These are decorative, unusual and attractive, rosettes of fleshy leaves, large or small; some are cobwebed, as illustrated. Flowers pink or yellow. Ea. $30 \mathrm{c} ; 3$ for $75 \mathrm{c}$.

SHORTIA galacifolia (Oconee Bells). One of the very finest of our native plants, now becoming rare. The evergreen leaves assume lovely Autumn tints. The exquisitely fringed white flowers appear in April. Requires an acid soil and shade. 4 in. Ea. 50 c; 3 for $\$ 1.30$.

SILENE alpestris (Catchfly). Glossy deep green foliage with dainty white flowers with notched petals. June. 6 in. Ea. 30c; 3 for $75 \mathrm{c}$.

*hookeri. Beautiful pink fringed blossoms, for a choice spot. Ea. 50c; 3 for $\$ 1.30$.

pennsylvanica (Peat Pink). Recommended by Mrs. Wilder. A beautiful native with neat leaves which turn bronze in Fall. The flowers, in clusters, are a lovely pink. May. 8 in. Ea. 40 c; 3 for $\$ 1.00$.

schafta. Masses of bright pink in early Fall. 6 in. Ea. $30 \mathrm{c} ; 3$ for $75 \mathrm{c}$.

virginica (Firepink). Large vivid scarlet flowers in May and June. 6 in. E.a. 35c; 3 for 90 c.

*wherryi. Deep pink flowers in May. New. Ea. 50c; 3 for $\$ 1.30$.

SISYRINCHIUM (Blue-Eyed Grass). Grasslike foliage; small blue flowers, native. May. 6 in. Ea. $30 ; 3$ for $75 \mathrm{c}$.

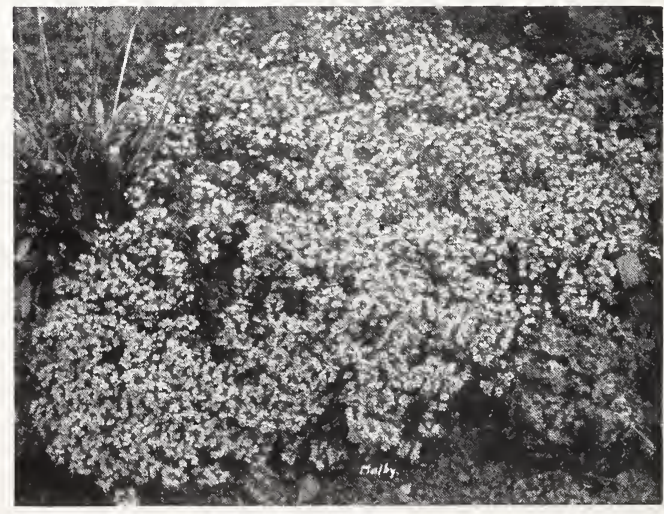

THYMUS SERPYLLUM ALBUM

*Sold out for Spring delivery, will be ready by Fall. 
THALICTRUM adiantifolium (Meadowrue). A foliage plant with maindenhair fern-like foliage. Pretty for association with border plants. Good in part shade or sun. $18 \mathrm{~m}$. Ea. 30c; 3 for $75 c$.

angustifolium. Fluffy masses of sulphuryellow flowers in June. $5 \mathrm{ft}$. Ea. $50 \mathrm{c} ; 3$ ior $\$ 1.30$.

THYMUS citriodorus (Thyme). Deep green, lemon scented foliage with lavender flowers. Shruib-like. 10 in. Ea. 30c; 3 for $75 \mathrm{c}$. serpyllum album. Forms a creeping mat of fine foliage with 2 profusion of white flowers sis July. One of the daintiest of plants. 1 in. Ea. 30c; 3 for 75 c.

- coccineum. Similar to the above, but the blossoms are of a bright pink, foliage bronzes in Winter. July. 1 in. Ea. 30c; 3 for $75 \mathrm{c}$.

- lanuguinosus. A treasure with gray-green, woolly foliage. Forms lovely mats which contrasts with other plants. 1 in. Ea. 30c; 3 for $75 \mathrm{c}$.

TIARELLA cordifolia (Foam Flower). A native with heart-shaped leaves and a spire of misty white flowers. Shade. 8 in. Ea. $30 \mathrm{c}$; 3 for $75 \mathrm{c}$.

TRILIIUM grandiflorum (Wake Robin). A beautiful native bulb for a shady spot. Exquisite white flowers in May. Attractive foliage. 12 in. 3 for $45 \mathrm{c} ; 100$ for $\$ 8.00$.

TROLLIUS (Globe Flower). Beautiful globeshaped blossoms of lovely shades of yellow or orange. We offer mixed varieties only. June. Ea. $50 \mathrm{c} ; 3$ for $\$ 1.30$.

TUNICA saxifraga (Coat Flower). Delicate foliage which in July is completely hidden by the masses of pale pink blossoms. Very dainty. 8 in. Ea. 30c; 3 for $75^{\circ}$.

VERONICA incana (Speedwell). From a tuft of silvery-gray foliage there appear in June spikes of pretty lavender flowers. 10 iu. Ea. $30 \mathrm{c} ; 3$ for $75 \mathrm{c}$.

pectinata. A prostrate gray-green creeper with a profusion of pretty blue and white flowers in June. 5 in. Ea. 30c; 3 for $75 c$.

prostrata. Fine mat of green foliage, at the ends of which in May appear the periwinkle blue flowers in abundance. 6 in. Ea. 30c; 3 foi 75 c.

repens. A wee little mite that makes a fine mat of pretty foliage which is starred in May with pale blue blossoms. 1 in. F.a. $30 \mathrm{c} ; 3$ for $75 \mathrm{c}$.

rupestris. A creeping variety with fine foliage and spikes of deep blue flowers in May. 5 in. Ea. 30c; 3 for 75 c.

- albus. Similar to the above, but with white flowers and blooming in May. 5 in. Ea. $30 \mathrm{c}$; 3 for $75 \mathrm{c}$.

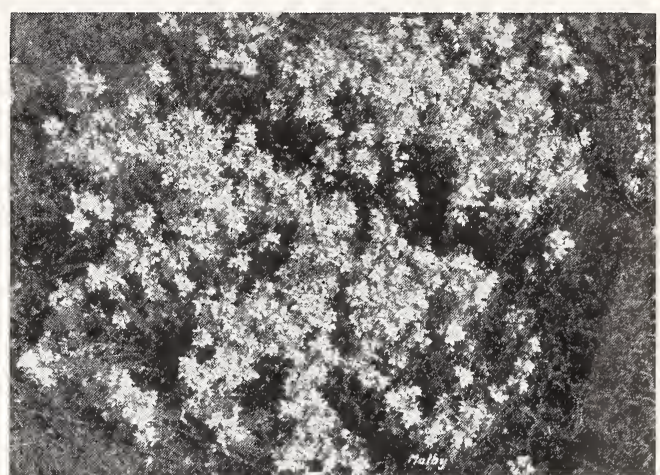

VERONICA PROSTRATA

VERONICA-Cont'd

- "Heavenly Blue." Dwarfer, deep blue flowers in early May, fine for between stepping stones. 3 in. Ea. 50c.

- rosea. Creeping mat, with mauve pink flowers in May. Ea. 40c; 3 for $\$ 1.00$.

saxatile. Dark, small, thick leaves; bright blue flowers. 4 in. Ea. 50c; 3 for $\$ 1.30$.

spicata erica. A variety with heather-like blooms and upright in growth. Lovely pink flowers in June. Fine for cutting. 18 in. Ea. 30c; 3 for $75 c$.

spuria. Spikes of amethyst blue flowers. Fine for cutting or for the border. 18 in. Ea. $30 \mathrm{c}$; 3 for $75 \mathrm{c}$ (June).

"True Blue." Brilliant, rich blue flowers June, July. 12 in. Ea. 35c; 3 for 90c.

VINCA minor (Periwinkle). A rapid growing evergreen ground cover with very pretty blue flowers in May. 4 in. Ea. 30c; 3 for $75 \mathrm{c}$.

VIOLA cornuta alba. Dainty, surprised faces of pure white. A good bloomer. Ea. 30c; 3 for $7 \bar{c} c$.

lutea splendens. Rich golden yellow. Ea. $30 \mathrm{c}$; 3 for $75 \mathrm{c}$.

"Jersey Gem." One of the best in cultivation. Rich, raisin-purple flowers during the whole season. Very choice. 8 in. Ea. $35 \mathrm{c}$; 3 for $85 \mathrm{c}$

pedata (Birds-foot violet). A lovely native violet which should be grown only in acid soil. The flowers are soft lavender and purple. May. 4 in. Ea. 25c; 3 for 60 c.

- linearifolia. An exceptionally choice vioiet for acid soil with soft lavender flowers in May. 3 in. Ea. 25c; 3 for 60 c.

tricolor ("Johnny-jump-up"). These bright faced, cheery "Johnnies" should be in every garden in the land. Always in bloom. Purple and yellow. 8 in. Ea. $15 \mathrm{c} ; 3$ for $40 \mathrm{c}$. 


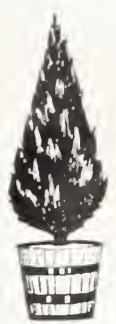

\title{
Dwarf Trees and Shrubs
}

\author{
(Evergreen and deciduous)
}

For accentuating the high lights in the rock garden and for breaking up the monotony of low planting in the home grounds. They add brilliant color in the Spring garden and delightful cheer during the long, dreary IVinter days when evergreens show up to such advantage.

We have a delightful assortment of these beautiful shrubs in various pastel shades and in various sizes.

Customer's selection will be charged at value of stock selected.

AZALEA. When in bloom the whole bush is a mass of color varying in tones of pink, yellow and orange, according to variety. Some are evergreen, others deciduous.

calendulacea (Flame Azalea). Orange-yellow to flame-red. Size 18 to 24 in. Ea. $\$ 3.50$.

“Ghent Hybrids." Various shades. 15 to 18 in. Ea. $\$ 4.00$ and upwards.

hinodegiri. Bright cherry-red flowers. Size 8 to 10 in. Ea. $\$ 2.00$.

hinomayo. Flowers soft clear pink. Size 10 to 12 in. Ea. $\$ 2.50$.

indica alba. Pure white flowers. Size 12 to 15 in. Ea. $\$ 2.50$.

kurume. "Pink Pearl." 8 to 10 in. Ea. $\$ 2.25$.

mollis. Large flowers in various shades of orange, yellow and red. Size 15 to $18 \mathrm{in.}$ Ea. $\$ 4.00$.

BUXUS suffruticosa (Dwarf Boxwood). A compact evergreen shrub. Useful for edging formal beds. Larger plants in limited quantity. Size 3 to 4 in., per $100, \$ 20.00$; 4 to 6 in., per $100, \$ 25.00$.

CALLUNA vulgaris (Scotch Heather). An airy, graceful evergreen shrublet with delightful lavender flowers in August. The famed Scotch Heather. Fine for the rock garden. Ea. 85c.

vulgaris alba. The white flowering form of the above which isdelightful for association with the lavender form. Ea. 85c.

CHAMAECYPARIS pisifera plumosa aurea. Rich yellow-tipped foliage. Good for contrasts. Size 18 to 24 in. Ea. $\$ 3.50$.
COTONEASTER adpressa (Rockspray). Excelent low growing shrub with spreading branches which are crowded with glossy leaves. Red berries in Autumn. Choice. Fine specimen, well-grown plants. Ea. \$2.00. dammeri radicans. A prostrate creeper with delightful foliage and red berries that last well into the Winter months. Choice. Ea. $\$ 2.00$.

horizontalis. Horizontally spreading branches well filled with fine glossy foliage. Red berries in Winter. Ea. $\$ 1.50$.

DAPHNE cneorum (Garland Flower). A charming evergreen shrub with whirls of fine foliage and terminal clusters of the most fragrant pink flowers in Spring and again in the late Fall. Ea. $\$ 2.00$.

ERICA carnea (Heather). A fascinating little evergreen shrub with pink flowers in April set off by its delightful foliage. Ea. \$1.00.

FORSYTHIA spectabilis (Golden Bell). A superb early blooming shrub whose bellshaped yellow flowers are arranged along the branches in large quantities and before the leaves appear. Specimens. Ea. \$2.00.

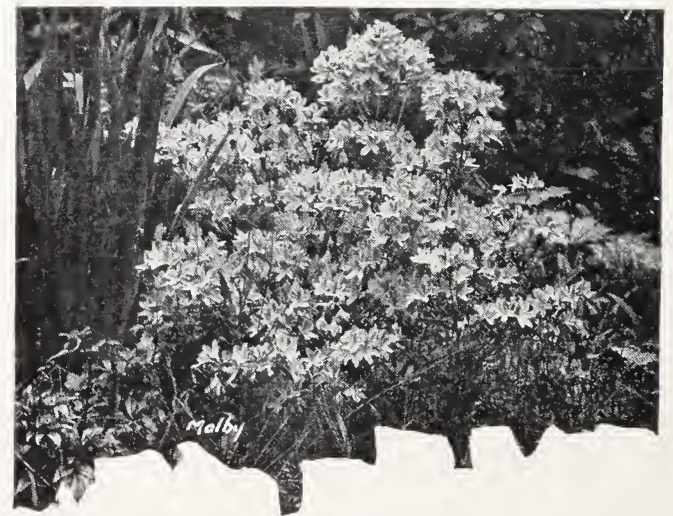

AZALEAS IN ROCK GARDEN 


\section{DWARF TREES AND SHRUBS-Cont'd}

ILEX glaber (Inkberry). A hardy native evergreen shrub with dark oval foliage. Size 15 in. Ea. $\$ 2.50$.

opaca (American Holly). Glossy evergreen foliage. $2 \frac{1}{2}$ to $3 \mathrm{ft}$. Ea. $\$ 4.50$.

JUNIPERUS chinensis pfitzeriana. Broad pyramidal evergreen, spreading branches; grayish-green foliage. Size 1 to $2 \mathrm{ft}$., $\$ 3.00$; 2 to $3 \mathrm{ft}$., $\$ 5.00$.

sargenti. A really splendid evergreen with prostrate branches. A trailing species which adds dignity to the home grounds planting or the rock garden. Fine specimens. 8 to 12 in. Ea. $\$ 3.50$.

horizontalis. Another beautiful trailing evergreen which, as an individual specimen or in group planting, is always delightful. 12 to 15 inn. Ea. $\$ 3.00$

KALMIA latifolia (Mountain Laure1). Broadleaved evergreen, clusters of pale pink flowers. Other sizes available. Size 15 to 18 in. Clump $\$ 2.00$.

LEIOPHYLLUM buxifolium (Sand Myrtle). Evergreen shrub, small shiny leaves. Flowers white in clusters at end of stems. Needs acid soil. 6 to 8 in. Ea. $\$ 1.00$.

LEUCOTHOE catesbaei. An evergreen with drooping sprays of white flowers and glossy leaves which turn bronze in Winter. Size 18 in. Ea. $\$ 1.25$.

LONICERA nitida (Bush Honeysuckle). A graceful shrub with small shining leaves, turning rich purple tints in Autumn. Very choice. Specimens 21/2 ft. Ea. \$2.25.

pileata. A fine dwarf shrub of spreading habit and yellow flowers, followed by purple berries in the Fall. Box-like leaves. Ea. $\$ 1.00$.

PACHISTIMA canbyi. A good evergreen low growing shrub that makes a fine ground cover. Ea. 75 c; 3 for $\$ 2.00$.

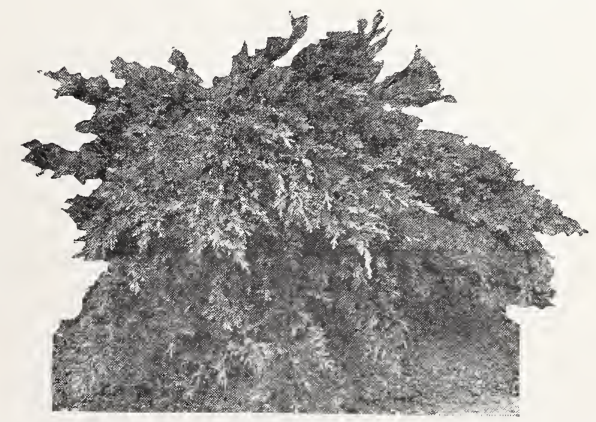

JUNIPERUS

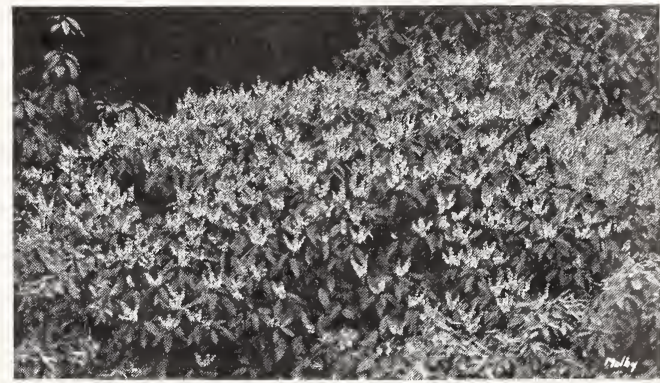

PIERIS FLORIBUNDA

PHOTINIA villosa. A tall growing shrub with scarlet berries, splendid foliage. Specimens 4 to $6 \mathrm{ft}$. Ea. $\$ 6.00$.

PICEA canadensis albertiana (Dwarf Alberta Spruce). A symmetrical evergreen that stays in scale for many years. Very slow growing. Dense, fine foliage. Size 6 to 8 in. Ea. $\$ 2.75$.

PIERIS floribunda. A low growing, distinctive evergreen shrub with festoons of white flowers in April. Size 12 in. Ea. $\$ 2.50$.

PINUS montana mughus. Low, dense evergreen growth. Very hardy. 12 to 15 in Ea. $\$ 3.00$.

RHODODENDRON carolinianum. A superb evergreen shrub, compact, bushy growth, with beautiful pink flowers in early Spring. Size 15 to 18 in. Ea. $\$ 4.00$.

SALIX repens argentea (Silver Creeping Willow). Gray-green foliage, a spreading shrub of varying heights. Ea. $\$ 1.00$.

SPIREA "Van Houttei." A splendid shrub with graceful sprays of white flowers in Spring. Specimens 4 to $5 \mathrm{ft}$. Ea. $\$ 1.50$.

TAXUS canadensis (Canada Yew). Widespreading evergreen for part shade. Deep crimson berries. 12 to 18 in. Ea. $\$ 3.50$.

cuspidata (Japanese Yew). Desirable hardy foliage almost black. 15 to 18 in. Ea. $\$ 4.00$.

- densa. 8 to 12 in. Ea. $\$ 4.00$.

- nana. 18 to 21 in. Ea. $\$ 8.00$

VACCINIUM vitis-idaea minor. Pink flowers. bright red berries, good evergreen foliage about the size of boxwood. Requires an acid soil. Ea. $\$ 1.00 ; 3$ for $\$ 2.50$.

VIBURNUM carlesi. Clustered pale pink flowers suggesting trailing arbutus, deliciously fragrant. Size 12 to 18 in. Ea. \$1.75. 


\section{GARDEN SUNDRIES}

\section{$\mathrm{ADCO}$}

Artificial Stable Manure. Make it of grass clippings, weeds, etc., in your own garden. Directions sent with each shipment.

25 lb. bags, each

(Enough for 12 wheelbarrow loads of garden waste, making $1 / 2$ ton of manure.)

150 1b. bags, each

$\$ 10.50$

(Enough for a heap $10 \mathrm{ft}$ × $10 \mathrm{ft}$. $\times 6$ ft., making about three tons of manure.)

\section{ALUMIUM SULPHATE}

For producing an acid soil-use $1 \mathrm{lb}$. to a square yard; repeat if necessary.
10 lbs.
$\$ .75$
$50 \mathrm{lbs}$.
$1001 \mathrm{bs}$
5.00

\section{EARTHENWARE FLOWER POTS}

\section{Height and}

Width Inside

2 inch

Each Doz. $100 \quad 1000$

3 “"

$\$ .03 \quad \$ .25 \quad \$ 1.15 \quad \$ 10.15$

“

$\begin{array}{llll}.06 & .40 & 1.95 & 17.55\end{array}$

$\begin{array}{llll}.07 & .50 & 4.00 & 27.00\end{array}$

,

$\begin{array}{llll}.10 & .75 & 5.40 & 48.60\end{array}$

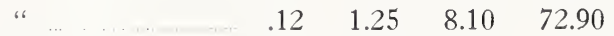

$\begin{array}{rrrr}\text { " } \quad . . . . .20 & 2.00 & 13.50\end{array}$

$\begin{array}{llll}\cdots & .25 & 2.75 & 19.50\end{array}$

$\begin{array}{llll}\text { " } & .35 & 4.00 & 30.00\end{array}$

$\begin{array}{lrrr}\because & .50 & 5.50 & 40.50\end{array}$

$\begin{array}{lrrr}\text { a } & 1.00 \quad 11.00 \quad 82.50\end{array}$

$\begin{array}{rrrr}\text { “..... } & 1.50 \quad 17.50 \quad 135.00\end{array}$

Other sizes and varieties if desired.

\section{LABLES, Painted Pot}

$\begin{aligned} 4 & \text { inch } \\ 4 \mathrm{~T} / 2 & \text { inch } \\ 5 & \text { inch } \\ 6 & \text { inch } \\ 8 & \text { inch } \\ 10 & \text { inch } \\ 12 & \text { inch }\end{aligned}$

100

1000

$\$ 0.35$

.40

.45

.55

1.60

1.75

2.25

$\$ 2.25$

2.75

3.00

3.50

9.00

11.00

14.00

\section{LABELS, TREE}

If wanted by parcel post, add $10 \mathrm{c}$. per 100 , 25c. per 1000 for postage.

$\begin{array}{ccr} & 100 & 1000 \\ \text { Copper Wire. Painted } & \$ 0.50 & \$ 3.25\end{array}$

\section{PEAT MOSS}

Granulated (imported) soil improver. Makes light soil retentive of moisture; makes heavy soil light. Excellent for Azaleas, Rhododendrons and Evergreens. $\mathrm{Pk}$. for $50 \mathrm{c}$; per bale (of about 200 lbs.) $\$ 4.50$.

\section{SOIL TESTKIT, "La Motte"}

All equipment necessary for soil tests and directions, as to how to change soil reaction, contained in a mailing tube. This can be readily carried in the pocket. $\$ 2.00$ each.

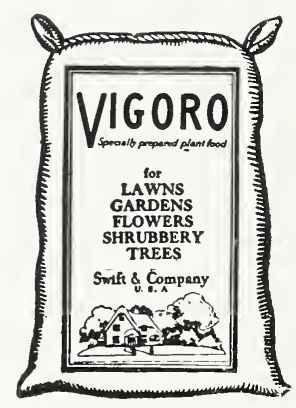

\section{VIGORO}

A specially prepared plant food for trees, lawns, vegetables, flowers and greenhouse plants. Directions on each package. $5 \mathrm{lbs}$. for $75 \mathrm{c}$., $\$ 1.75$ per $25 \mathrm{lbs}$., $\$ 3.00$ per 50 lbs., $\$ 5.00$ per 100 lbs.

\section{WATER CAN}

(Wotherspoon's). Extra heavy, oval-long spout. Each can equipped with a fine and a coarse rose.

6 quart

10 quart 


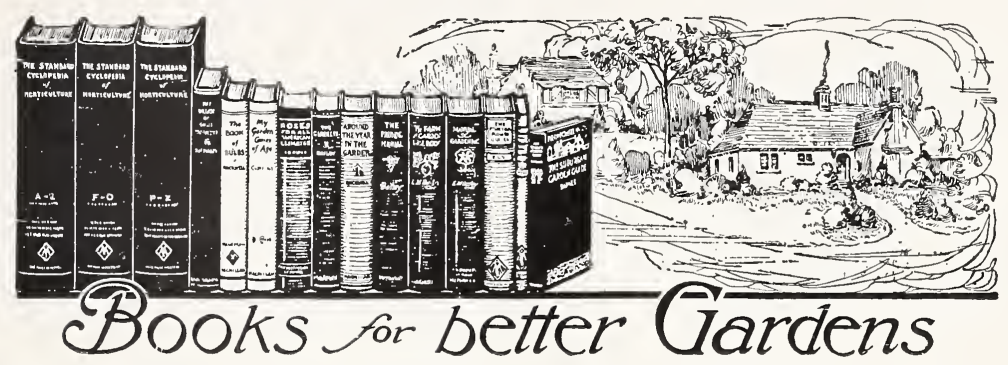

A LitTle BOOK OF CLIMBing PLANTS, by Proí. Alfred C. Hottes.

$\$ 1.75$

AMERICAN ROCK GARDENS, by Stephen F. Hamulin.

BIRDS OF THE WILD-How to Make Your Home Their Home, by Frank C. Pellett... 1.75

BULBS THAT BLOOM IN THE SPRING, by T. A. Weston

CONTINUOUS BLOOM FOR GARDENS IN AMERICA: What, Where, When to Plant,

by Louise Shelton.

CULINARY HERBS, by M. G. Kains

EVERGREENS FOR THE SMALL PLACE, by F. F. Rockwell

1.10

1.00

FERTILIZERS, by E. B. Voorhees, revised by S. B. Haskell

2.50

GARDEN CINDERELLAS (Lilies), by Helen M. Fox.

HOW TO GROW ROSES, by Robert Pyle, J. Horace McFarland and G. A. Stevens. A

new edition, completely revised and brought down to date. Illustrated with numerous

color and halftone plates.

HARDY EVERGREENS, by F. A. Schrepfer

HARDY BULBS FOR AMATEURS, by Reverend Joseph Jacob

LILAC CULTURE, by John C. Wister.

MANUAL OF CULTIVATED TREES AND SHRUBS, by Alfred Rehder..

OUR GARDEN FLOWERS, by Harriet L. Kzeler

OUR WILD ORCHIDS, by Frank Morris and Edward A. Eames

7.50

PLANTS' NAMES, by T. S. Lindsay.

1.00

ROCK GARDEN PRIMER, by Archie Thornton

2.00

ROCK GARDEN AND ALPINE PLANTS, by Henri Correvon. Edited by Leonard

Barron. Written for American conditions. The illustrations include eight color plates

and numerous halftones. To be issued in May. (Price on application.)

RHODODENDRONS FOR AMATEURS, byE. H. M. Cox

ROOF GARDENING, by Ida Mellen.

SPRING FLOWERING BULBS, by C. L. Thayer

STARTING EARLY VEGETABLES AND FLOWER PLANTS UNDER GLASS, by

C. H. Nissley

THE BOOK OF ANNUALS, by Prof. Alfred C. Hottes

THE BOOK OF BULBS, by F. F. Rockwell.

THE BOOK OF PERENNIALS, by Prof. Alfred C. Hottes.

THE BOOK OF SHRUBS, by Prof. Alfred C. Hottes

THE BOOK OF WATER GARDENING, by Peter Bissat

THE CHRYSANTHEMUM AND ITS CULTURE, by E. A. White $\ldots . . \ldots . . .2 .00$

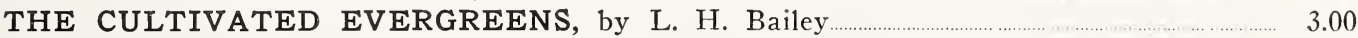

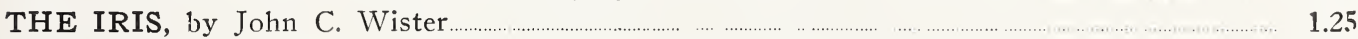

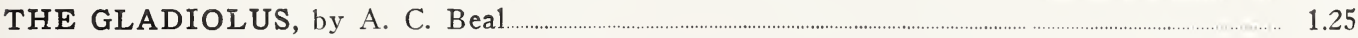

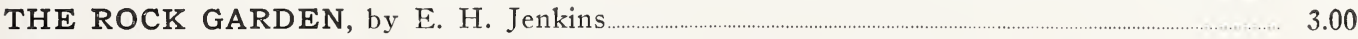

THE SEASONS IN A FLOWER GARDEN, by Louise Shelton ................................. 2.00

THE STANDARD CYCLOPEDIA OF HORTICULTURE, edited by L. H. Bailey .......... 25.00

WATER GARDENS AND GOLDFISH, by Robert V. Sawyer and Edwin H. Perkins........ 1.50 
$\underline{\mathrm{NOTES}}$

The Logan Nurseries MARY F. WRIGHT, Proprietor Ambler - - Pennsylvania 